DOI: https://doi.org/10.12797/Politeja.15.2018.53.05

\title{
Jadwiga BŁAHUT-PRUSIK
}

Uniwersytet Warmińsko-Mazurski w Olsztynie jadwiga.blahut@uwm.edu.pl

\section{POMIĘDZY BEZPIECZEŃSTWEM, SEKURYTYZACJA A JĘZYKIEM}

\section{ABSTRACT Between security, securitization and language}

The article analyzes relations between security, securitization and language. The issue was presented in the broader context of the specificity of the modern reality dominated by what Ulrich Beck has described as the 'global risk'. Various forms of global danger make security the category through which the reality is more frequently depicted and explained. In the face of risk, securitization and its specific language have become today the major means of providing security.

Key words: security, language, risk, securitization

Słowa kluczowe: bezpieczeństwo, język, ryzyko, sekurytyzacja 
Niepewność jest teraz statym elementem świata, w którym żyjemy. Chodzi o to, że w każdym wieku następuje punkt zwrotny, nowy sposób widzenia i rozumienia spójności świata. Żyjemy w wieku ryzyka, a niepewność jest jego ostateczna cechą ${ }^{1}$.

\section{WPROWADZENIE}

Bezpieczeństwo stanowi obecnie jedną z najczęściej przywoływanych i analizowanych kategorii wyrażających sposób bytowania człowieka i jego odnoszenia się do świata. Coraz szerszy kontekst poznawczy i instrumentalny, w jakim posługujemy się tym pojęciem, sprawia, że za jego pomocą usiłujemy wyjaśnić zarówno motywy, cele działania, jak i narzędzia ich realizacji. Wraz z tym bezpieczeństwo obok znaczenia negatywnego, wciąż fundamentalnego dla tego terminu, zyskało sens pozytywny, tj. gdy przestało być odnoszone wyłącznie do kwestii egzystencjalnego przetrwania, a powiązano je z jakością ludzkiej egzystencji - godną formą trwania - stało się kategorią wielokontekstową i interdyscyplinarną. Połączenie bezpieczeństwa z wieloma obszarami ludzkiego życia spowodowało, że jego realizacja jest dużo trudniejsze aniżeli wówczas, gdy odnoszono je jedynie do aspektu militarnego ${ }^{2}$. Co więcej, okazało się, że jest niemożliwe do osiągnięcia we wszystkich sferach jednocześnie. Godna forma trwania, wyrażająca się w możliwości zaspokojenia potrzeb wyższego rzędu, w różnych obszarach życia jest odmiennie realizowana, inne kryteria wyznaczają sposoby i narzędzia jej uzyskiwania. Ponadto w zasadniczej mierze przybiera ona charakter wartościujący i stopniowalny, co oznacza, że sprowadza się do subiektywnego poczucia bezpieczeństwa lub jego braku. W pozytywnym ujęciu bezpieczeństwo traci swoje pierwotne, etymologiczne znaczenie (lac. sine cura - bez pieczy). Względnie stały stan niewymagający troski ani opieki nie przystaje do warunków, w których bezpieczeństwo staje się procesem i wymaga nieustannego wysiłku, działania. Niegdyś wyznaczany przez naturę czy Boga stan zmienił się w proces, a w nim to, co wcześniej obiektywne, silnie determinujące bezpieczeństwo, ostatecznie straciło swoje znaczenie. Bezpieczeństwo stało się osiągalne jedynie w perspektywie ludzkich możliwości i jako takie pozostaje subiektywne, niepewne i tymczasowe. Przybiera ono taki charakter, gdyż także zagrożenia - niegdyś postrzegane jako względnie statyczne, a przede wszystkim rozpoznawalne - przynależą do procesu jako wytwory społecznej, kulturowej i politycznej ewolucji.

Rozumienie i sposoby realizacji bezpieczeństwa (podobnie jak każdej innej wartości) zdeterminowane są przez określoną epokę i dominującą w niej koncepcję rzeczywistości. Jesteśmy w stanie zrozumieć określone zjawisko tylko wówczas, gdy uchwycimy

C. Coker, War in an Age of Risk, Cambridge 2009, s. 62.

2 Na temat wąskiej definicji bezpieczeństwa zob. K.M. Fierke, Critical Approaches to International Security, Cambridge 2015, s. 17-23; B. Buzan, O. Wæver, J. de Wilde, Security. A New Framework for Analysis, London 1998, s. 10-15; M. Bourne, Understanding Security, New York 2014, s. 27-41. 
jego szerszy kontekst. Tym szerszym tłem odczytywania i interpretacji współczesnych zjawisk stał się proces globalizacji. Specyfika naszych czasów, wyznaczona przez to, co Ulrich Beck określił mianem „globalnego ryzyka”, czyni bezpieczeństwo jedną z głównych kategorii porządkujących rzeczywistość. Bezpieczeństwo jako stan odnoszony do coraz liczniejszych aspektów naszego życia, pozbawiony trwałych zasad realizacji, ulega rozmyciu, a wysiłki zmierzające do jego zapewniania są bardziej podatne na partykularne wpływy i manipulacje.

W obliczu globalnych zagrożeń głównym narzędziem realizacji bezpieczeństwa staje się sekurytyzacja. Pojęcie to zostało wprowadzone do debaty nad bezpieczeństwem przez przedstawicieli tzw. szkoły kopenhaskiej. Jest rozumiane jako dyskursywna technika, za pomocą której decydenci, państwa i rządy dążą do przedstawienia jakiejś sprawy jako egzystencjalnego zagrożenia dla bezpieczeństwa bytu społecznego, a istniejącego stanu jako wymagającego niezwłocznego i skutecznego działania. Niemniej jednak samo uznanie zagrożenia za egzystencjalne stanowi jedynie „sekurytyzacyjny ruch”. Z sekurytyzacją mamy do czynienia wówczas, gdy publiczność uzna określone zagrożenie za takie, jakim mu je przedstawiono ${ }^{3}$. Jak wskazują przedstawiciele szkoły kopenhaskiej: doktadna definicja i kryteria sekurytyzacji sa utworzone przez intersubiektywne ustanowienia egzystencjalnego zagrożenia z wyartykutowaniem jego istotnych skutków po$l_{\text {litycznych }}{ }^{4}$. W sekurytyzacji wyraża się przyzwolenie na zastosowanie środków nadzwyczajnych w celu zapewnienia bezpieczeństwa. Sekurytyzacja jako technika polityczna okazuje się niezwykle skutecznym środkiem do generowania nowych obszarów działań politycznych, a co więcej, może być ona wykorzystywana w celu tworzenia podstaw do radykalnych odstępstw od panujących norm postępowania międzynarodowego ${ }^{5}$. Zdaniem Karin M. Fierke: koncepcja sekurytyzacji podkreśla dynamikę, w której pewne zagrożenia, w przeciwiensstwie do innych, zaczynaja być rozumiane w kategoriach bezpieczeństwa i wagi jego znaczenia jako akt interpretacji ${ }^{6}$. W tej perspektywie Ole Wæver sekurytyzację uznaje za to, co w teorii języka nazywane jest aktem mowy ${ }^{7}$ - ściśle łączy ją zatem z językiem. To akt mowy nadaje problemowi status zagrożenia, kreując w ten sposób rzeczywistość. W oparciu o to założenie w artykule ukazano, w jakiej mierze działania podejmowane w sytuacji nadzwyczajnej mogą skutkować obniżeniem poczucia bezpieczeństwa. Dotyczy to zwłaszcza zagrożeń globalnych, które najczęściej wymykają się możliwości przewidywania i przeciwdziałania. Celem ukazania relacji

Więcej na ten temat zob. M. McDonald, Constructing Security. Australian Security Discourse and Policy Post-2001, „International Relations” 2005, vol. 19, nr 3, s. 297-320, cyt. za: L. Walsh, J. Barbara, Speed, International Security, and "New War" Coverage in Cyberspace, "Journal of Computer-Mediated Communication" 2006, vol. 12, nr 1, s. 198; B. Buzan, O. Wrever, J. de Wilde, Security. A New Framework..., s. 23-26.

Tamże, s. 25.

Więcej na ten temat zob. W. Kostecki, Strach i potęga. Bezpieczeństwo międzynarodowe w XXI wieku, Warszawa 2012, s. 12-13.

$6 \quad$ K.M. Fierke, Critical Approaches..., s. 111.

Zob. O. Wrver, Security, the Speech Act, [online] http://www.academia.edu/2237994/Security_the_ Speech_Act_-_working_paper_1989, s. 41-45, 18 III 2017. 
zachodzącej między bezpieczeństwem a ryzykiem, między bezpieczeństwem a sekurytyzacją, między bezpieczeństwem a językiem posłużono się przykładem zjawiska globalnego terroryzmu oraz walki z nim. Artykuł ma na celu ukazanie „wieku ryzyka” jako ściśle skorelowanego z bezpieczeństwem i sprzyjającego sekurytyzacji, która okazuje się jednym z głównych narzędzi służących osiąganiu bezpieczeństwa; skądinąd narzędziem niosącym ze sobą również groźbę uczynienia świata bardziej brutalnym i niesprawiedliwym - zamiast bezpieczniejszym i bardziej stabilnym.

\section{BEZPIECZEŃSTWO A RYZYKO}

Właściwa bezpieczeństwu wielokontekstowość nadaje mu abstrakcyjny charakter, czyni je przedmiotem ontologicznej, epistemologicznej i aksjologicznej refleksji. W perspektywie filozoficznej bezpieczeństwo najczęściej postrzegane jest w wymiarze aksjologicznym - jako coś, co uznajemy za szczególnie cenne, warte wysiłków i osiągnięcia. Jak każdej innej wartości, tak również bezpieczeństwu odpowiada wartość negatywna jako zaprzeczenie i pojęciowe uzupełnienie zarazem. W przypadku bezpieczeństwa jest nią zagrożenie (niebezpieczeństwo). Z tego powodu w ogólnym sensie bezpieczeństwo przeciwstawiane jest rozbiciu, dekompozycji, zniszczeniu lub groźbie zniszczenia $i$ degradacji podmiotów ludzkich, zazwyczaj paralizujacej ich normalne funkcjonowanie, wypetnianie programu życiowego i realizacje ontologicznego standardu jednostkowości, spoteczności i gatunkowości cztowieka ${ }^{8}$. Realizacja bezpieczeństwa polega zatem na rozpoznaniu, przeciwdziałaniu i eliminacji zagrożeń rozumianych jako stany i sytuacje uniemożliwiające przetrwanie, rozwój czy doskonalenie jakości trwania.

Obecnie często doświadczamy sytuacji, w których przeciwdziałanie zagrożeniom jest niemożliwe. Dzieje się tak z prostej przyczyny: stają się one coraz mniej przewidywalne. $Z$ tego powodu, obok antywartości w postaci zagrożenia, bezpieczeństwo coraz częściej dyskutowane jest w kontekście ryzyka, jego globalnych form oraz ich skutków. Narracja ryzyka jest narracja ironii. Narracja ta dotyczy mimowolnej satyry, optymistycznej daremności, w której wysoko rozwinięte instytucje nowoczesnego spoteczeństwa: nauka, państwo, gospodarka i wojskowość próbują przewidzieć to, czego przewidzieć nie sposób ${ }^{9}$ tak Ulrich Beck ujął istotę naszej dzisiejszej sytuacji. Ironia wyraża się w fakcie, że świat, który stworzyliśmy, przepełnia ryzyko powstałe nie z powodu zaniedbań czy niepowodzeń nowoczesności, a z racji jej sukcesów. Ryzyko jest wtórnym następstwem zwycięskiej modernizacji ${ }^{10}$. Ryzyko demaskuje bezpieczeństwo jako stan, którego realizacja tylko pozornie lub tymczasowo spełnia nasze oczekiwania. W dłuższej perspektywie sukces może jednak nieść ze sobą odwrotny skutek. Ryzyko wywołuje trwałą niepewność co do skutków działań podejmowanych na rzecz zapewnienia bezpieczeństwa.

8 J. Lipiec, Świat wartości. Wprowadzenie do aksjologii, Kraków 2001, s. 208.

9 U. Beck, Living in the World Risk Society, „Economy and Society” 2006, vol. 35, nr 3, s. 329.

10 Tenże, Spoteczeństwa światowego ryzyka. W poszukiwaniu utraconego bezpieczeństwa, przeł. B. Baran, Warszawa 2012, s. 20-21. 
Ryzyko powstaje m.in. w rezultacie fragmentarycznie pojmowanych i realizowanych założeń bezpieczeństwa. Stawia nas w obliczu świadomości daleko idących konsekwencji naszych działań, które nie ograniczają się ani do prostych przyczynowo-skutkowych zależności, ani do obszaru, w jakim podejmujemy działania w celu uzyskania bezpieczeństwa, ani do czasowej perspektywy służącej wyeliminowaniu zagrożeń ${ }^{11}$. Brak systemowego, holistycznego podejścia do kwestii bezpieczeństwa determinuje kształt dzisiejszych zagrożeń. Według Becka głównym źródłem zagrożeń ludzkości ${ }^{12}$ stała się nasza niewiedza, niemożność przewidzenia skutków własnych działań, a co za tym idzie - całkowity brak kontroli nad nimi. Oznacza to, że racjonalność, będąca podstawą kalkulacji ryzyka, jak również realizacji założeń bezpieczeństwa, przestała być adekwatna do sytuacji, w której coraz częściej mamy do czynienia z trudnymi do przewidzenia katastrofami ${ }^{13}$. Przestrzenna, czasowa i społeczna delokalizacja form ryzyka sprawia, że bezpieczeństwo - mimo iż oparte na wiedzy i doświadczeniu - wymyka się znanym i stosowanym dotąd metodom jego zapewniania. Chodzi tu zarówno o jego negatywny, jak i pozytywny wymiar. Głównym powodem tego stanu jest to, że kalkulacja ryzyka obok doświadczenia i racjonalności funkcjonuje w obszarze tego, co nierozpoznawalne, a co w zasadniczej mierze odnosi się do wyobraźni, podejrzeń, fikcji i lęku ${ }^{14}$ (można by rzec: tego, co de facto irracjonalne). Radykalniejsze stanowisko w tej kwestii prezentuje Zygmunt Bauman. Twierdzi, że: zachowanie ztożonych systemów wielu niezależnych jest ipozostaje na zawsze ni eprze wi dy waln e. Nieprzewidywalne nie tylko z powodu naszej niewiedzy, niedbalstwa lub gapiostwa, ale ze względu na naturę samych tych systemów. Ponieważ nasz swiat jest najbardziej ztożonym systemem, jaki potrafimy sobie wyobrazić, jego przysztość jest wielk a niewiadoma i pozostaje nia bez względu na to, co zrobimy. Prognozy moga opierać się tylko na domystach, a darzenie ich zaufaniem wiaże się zawsze z ogromnym ryzykiem ${ }^{15}$.

Taki punkt widzenia częściej wiąże bezpieczeństwo z pojęciem ryzyka niż zagrożenia. Ryzyko uświadamia nam możliwość pojawienia się tego, czego na etapie zapobiegania lub eliminacji zagrożeń nie jesteśmy w stanie przewidzieć. Wydłuża nie tylko czasową perspektywę, w jakiej bezpieczeństwo jest rozpatrywane, ale również czyni je stanem nietrwałym i płynnym.

11 Z tego też powodu bezpieczeństwo domaga się optyki systemowej, tj. analizy różnych, choć zarazem powiązanych ze sobą, współzależnych jego typów. Na temat teorii systemów zob. Ogólna teoria systemów. Tendencje rozwojowe, red. G.J. Klir, przel. C. Berman, Warszawa 1976; W. Gasparski, pod hasłem Systemów teoria, [w:] Filozofia a nauka. Zarys encyklopedyczny, red. M. Iżewska, Wrocław 1987, s. 696-703.

12 Niezależnie od tego, jaką zastosujemy klasyfikację zagrożeń globalnych, możemy z jednej strony wskazać na te, które stanowią niezamierzony skutek uboczny decyzji podejmowanych w procesie modernizacji (wśród których U. Beck wyróżnia zagrożenia ekologiczne i finansowe), z drugiej - doświadczamy również zagrożeń celowo wywoływanych przez człowieka (zagrożenia terrorystyczne). Obok przypadku pojawia się zatem również zamysł, podszyty złą intencją, całkowicie wymykający się kontroli.

13 Zob. U. Beck, Spoteczeństwa światowego ryzyka..., s. 75-79, 83.

14 Zob. tamże, s. 82-85. 
Według Becka, wkraczając w nowy etap nowoczesności, w którym za sprawą pojawiających się różnych form globalnego ryzyka dominującą rolę zaczyna odgrywać bezpieczeństwo, stanęliśmy w obliczu całkowitej zmiany politycznych, społecznych i kulturowych doświadczeń. U. Beck wiąże ryzyko z przewidywaną katastrofą. Ryzyko jest stanem wirtualnym, nie jest realne, co najwyżej bardziej lub mniej prawdopodobne. W chwili, gdy staje się prawdziwe (np. przybierając postać ataku terrorystycznego), zmienia się w katastrofę. W takiej sytuacji oczekiwanie na dalsze ataki, inflację, wojny lub ograniczenie swobód obywatelskich zostaje już przeniesione gdzie indziej ${ }^{16}$. Ponieważ ryzyko jest kategorią odnoszącą się nie do istniejących, lecz przyszłych i tylko prawdopodobnych zjawisk, sama jego natura wyklucza pewną wiedzę o nim. Sprawia to, że zawsze istnieje groźba, iż decyzje podejmowane na rzecz przeciwdziałania zagrożeniom mogą przyczyniać się do utraty poczucia bezpieczeństwa. To w istocie niewiedza aktywizuje nasze działania zmierzające do osiągnięcia bezpieczeństwa. Świadomość ryzyka i towarzysząca mu niepewność powodują, że uzależniliśmy się od pozornego poczucia bezpieczeństwa i kontroli ${ }^{17}$. Ta świadomość wywołuje w nas stałe poczucie konieczności przeciwdziałania zagrożeniom, z którymi bezpośrednio wiąże się ryzyko. Okazuje się jednak, że w obliczu nieprzewidywalności konsekwencji działań podejmowanych na rzecz bezpieczeństwa jesteśmy pozbawieni skutecznych narzędzi jego realizacji.

Według Becka głównym elementem zarządzania ryzykiem stała się dziś inscenizowana antycypacja zniszczeń i katastrof. To ona najczęściej prowokuje, a czasem wręcz wymusza działania prewencyjne, w następstwie których bezpieczeństwo wymaga priorytetowego traktowania. Niemniej jednak zagrożenia rozpatrywane z perspektywy ryzyka stają się istotne dopiero dzięki technikom wizualizacji, symbolicznym formom, mediom, inscenizacjom, oczekiwaniom, antycypacji - bez nich tracą znaczenie. Innymi słowy, mało istotne jest, czy żyjemy w świecie, który jest faktycznie bezpieczniejszy, gdyż antycypacja możliwych zniszczeń i katastrof wytwarza przymus działania. W tym kryje się ironia - ironia obietnicy bezpieczeństwa zapewnianego przez naukowców, firmy i rządy, która notabene przyczynia się do wzrostu ryzyka ${ }^{18}$. W następstwie tego, zagrożenia, stając się przedmiotem nieustannego inscenizowania i antycypowania, konsekwentnie przyczyniają się do obniżenia poczucia bezpieczeństwa. Inscenizacja $\mathrm{w}$ mass mediach czyni niebezpieczeństwo bardziej prawdopodobnym i nieuchronnym, jest źródłem szybko narastającego społecznego poczucia globalnych zagrożeń. W przekazie medialnym oraz $\mathrm{w}$ towarzyszącym mu dyskursie zagrożenia zaczynają żyć własnym życiem, poczucie ryzyka wzrasta wprost proporcjonalnie do częstotliwości ich nagłaśniania, inscenizacji w ludzkich umysłach i w zbiorowej wyobraźni. Przekaz medialny nie tylko opowiada o zagrożeniach, ale ma również potężną moc ich kreowania. W ten sposób aktywnie uczestniczy on w procesie sekurytyzacji, potwierdzając tezę przedstawicieli szkoły kopenhaskiej o tożsamości sekurytyzacji $\mathrm{z}$ aktem mowy - Austinowskim performatywem ocenianym jedynie pod względem

16 Zob. U. Beck, Living in the World..., s. 332.

17 Zob. tenże, Spoteczeństwa światowego ryzyka..., s. 83.

18 Zob. tenże, Living in the World..., s. 332. 
skuteczności (fortunności) ${ }^{19}$. W erze ryzyka obraz bezpieczeństwa pozostaje silnie zdeterminowany przez naszą wyobraźnię, gdyż nie zawsze poddaje się obiektywnym kalkulacjom, przeciwnie, zyskuje wysoce subiektywny charakter, zakorzeniony w danej kulturze. Jak zauważa Christopher Coker: I to jest wyzwanie, bo spoteczeństwom, podobnie jak i ludziom, nie jest tatwo argumentować swoje obawy. W przeciwieństwie do strachu obawa jest ugruntowana nie w teraźniejszości lub spostrzeżeniu, ale w wyobraźni. A wyobraźnia może sięgać daleko w przysztość. To dlatego postrzegamy siebie jako żyjacych w świecie, który Tony Blair określit mianem "post-bezpiecznego" ${ }^{20}$.

\section{BEZPIECZEŃSTWO A SEKURYTYZACJA}

W obliczu niemożliwości przewidywania zagrożeń bezpieczeństwo coraz częściej staje się sposobem zarządzania ryzykiem, a sekurytyzacja środkiem jego zapewniania. Wiek ryzyka sprzyja sekurytyzacji, a czasami wręcz ją wymusza. Implikując niepewność, ryzyko sprawia, że w rezultacie niewiedzy działania na rzecz bezpieczeństwa nabierają podobnego, przypadkowego charakteru. Problemem nie jest jednak to, że nagle realizacja bezpieczeństwa stała się niemożliwa. Rzecz w tym, że tradycyjne metody jego zapewniania przestały przystawać do zupełnie nowych warunków. Globalizacja dezaktualizuje tradycyjne metody i środki zapewniania bezpieczeństwa przez ustanowienie tego, co Manuel Castells nazwał „przestrzenią przepływów”21. W niej zaś różne formy bezpieczeństwa pozbawione zostają granic niezbędnych do jego urzeczywistniania, a przede wszystkim pewności, poczucia jego trwania. Do niedawna granice przestrzenne dostarczały względnie obiektywnego punktu odniesienia, stanowiącego warunek realizacji bezpieczeństwa i jego oceny jednocześnie. Dotyczy to granic, które określając podmiot i przedmiot bezpieczeństwa, ułatwiały jego realizację. Podmiotowo-przedmiotowa identyfikacja nie straciła znaczenia, lecz dziś mamy dużo większą świadomość zależności, jakie zachodzą między poszczególnymi podmiotami bezpieczeństwa, jak i w przedmiotowych obszarach jego urzeczywistniania. Świadomość ta zasadniczo zmniejsza poczucie bezpieczeństwa, którego osiągnięcie przez każdy z podmiotów i we wszystkich sferach działalności okazuje się niemożliwe. Historycznie sytuacja zmieniła się wraz z końcem zimnej wojny, gdy pojęcie bezpieczeństwa, obok wymiaru negatywnego, zyskało nowe, pozytywne znaczenie. $Z$ jednej strony to semantyczne poszerzenie sprawiło, że odeszliśmy od czysto militarnego rozumienia bezpieczeństwa, w którym zagrożenie dla przetrwania podmiotu stanowiło jasne kryterium jego realizacji. Z drugiej strony pozytywne znaczenie bezpieczeństwa, związane z ogólnie pojmowanym rozwojem, sprawiło, że zostaliśmy tego kryterium pozbawieni.

19 Zob. H. Stritzel, Security in Translation. Securitization Theory and the Localization of Threat, New York 2014, s. 26-30. Por. J.L. Austin, Jak dziatać stowami, [w:] J.L. Austin, Mówienie i poznanie. Rozprawy i wyktady filozoficzne, przeł. B. Chwedeńczuk, Warszawa 1993, s. 542-708.

20 C. Coker, War in..., s. 74.

21 Zob. M. Castells, The Information Age. Economy, Society and Culture, t. 1: The Rise of the Network Society, Oxford 2000, s. 495-497. 
Realizacja bezpieczeństwa pozytywnego dotyczy tak wielu obszarów ludzkiej działalności, że nie sposób wyznaczyć jednego kryterium stanowiącego odniesienie sytuacji ocenianych jako bezpieczne lub nie ${ }^{22}$. By określić jasne kryterium, musimy podjąć decyzję, jaki rodzaj bezpieczeństwa w określonych warunkach uznajemy za priorytetowy. Pod wpływem procesu globalizacji i wirtualizacji zatarly się również granice przestrzenno-czasowe, które wcześniej umożliwiały identyfikacje zagrożeń. Spowodowało to, że coraz częściej zagrożenia, a co za tym idzie - bezpieczeństwo - rozpatrywane są w związku z ryzykiem. Zniknęły także granice metafizyczno-aksjologiczne, które tworząc niegdyś obiektywne fundamenty rozumienia rzeczywistości, ustanawiały względnie stałe ramy i kryteria realizacji wielu wartości, w tym również bezpieczeństwa. Wraz z ich zanikiem bezpieczeństwo stało się osiągalne jedynie w perspektywie ludzkich możliwości i jako takie pozostaje subiektywne, niepewne i tymczasowe. Dotyczy to zwłaszcza bezpieczeństwa pozytywnego, które w przypadku różnych podmiotów może być odmiennie urzeczywistniane i odczuwane.

Gdy bezpieczeństwo zyskuje w znacznej mierze charakter intersubiektywny i uwarunkowany praktyką społeczną, zagrożenia stają się kwestią interpretacji i siły argumentu. Wojciech Kostecki zauważa: Bezpieczeństwo przypomina w tym ujęciu zjawisko znane z teorii języka: tworzenie faktów przez mówienie o nich ${ }^{23}$ - polityczny konstrukt zdeterminowany przez określone warunki. To z tego powodu sekurytyzacja, której narzędziem w pierwszej kolejności jest język, nabiera podstawowego znaczenia. Przez wypowiedzenie stowa "bezpieczeństwo" przedstawiciel państwa przenosi określone zdarzenie w szczególna dziedzinę i w związku z tym domaga sie specjalnego prawa do stosowania dowolnych przedsięwzięć w celu opanowania sytuacji ${ }^{24}$. Zwłaszcza kiedy zagrożenia są jedynie prawdopodobne, lecz w swoich ewentualnych skutkach niezwykle dotkliwe, język tworzy kategorie rozumienia i konstruowania rzeczywistości, a nawet manipulowania nią - starając się to prawdopodobieństwo skalkulować. Język, który w zasadniczej mierze determinuje nasze postrzeganie rzeczywistości, jej poznanie oraz wartościowanie, nieuchronnie wpływa na konkretne działania polityczne, procesy i struktury społeczne. Staje się najsilniejszym środkiem społecznego odziaływania, sterowania, interpretacji, porządkowania i współkonstytuowania rzeczywistości. Tego rodzaju antyreprezentacjonistyczne ujęcie ma swoje bezpośrednie implikacje dotyczące postrzegania i realizacji bezpieczeństwa. Jak widać, nasze poczucie bezpieczeństwa w dużym stopniu warunkuje język, którym mówimy nie tyle o samym bezpieczeństwie, co o jego zagrożeniach.

Bezpieczeństwo jako jeden z faktów kultury jest ściśle związane z językiem. O tym, jak istotną rolę w budowaniu bezpieczeństwa odgrywa język, przekonujemy się wówczas, gdy w obliczu określonych zdarzeń pojawia się słowna pustka, gdy nagle język za pomocą kategorii, terminów, znaczeń nie radzi sobie z próbą uporządkowania, a tym

22 Więcej na temat poszczególnych sektorów bezpieczeństwa (militarnego, gospodarczego, społecznego, politycznego, środowiskowego) zob. B. Buzan, O. Wæver, J. de Wilde, Security. A New Framework..., s. $49-162$.

23 W. Kostecki, Strach i potega..., s. 115.

24 O. Wæver, Securitization and Desecuritization, [w:] On Security, red. R.D. Lipschutz, New York 2005; cyt. za: tamże, s. 115. 
samym kontroli tego, co się wydarzyło. Ta werbalna bezsilność implikuje niemożność działania. Ilustracją tego faktu stały się wydarzenia z 11 września 2001 r. Nasza niemoc związana z trudnością zdefiniowania tego, co nie do końca rozpoznane, jak nazwał problem Jacques Derrida, ujawniła się już w samym posługiwaniu się określeniem „11 września”. Jego zwięzłość, wbrew pozorom, nie oznacza, że wypowiadając je, wszyscy wiemy, o czym mowa. Przeciwnie - to wyraz niemocy rozpoznania i sklasyfikowania tego, co jawi się jako zupełnie obce i niezidentyfikowane ${ }^{25}$. W podobnym duchu wypowiada się Richard Jackson. Podczas gdy oczywiste stały się fakty, nie było oczywiste, co one oznaczają i co zwiastują. Ataki terrorystyczne wytworzyły „znaczeniową pustkę" domagającą się natychmiastowego wypełnienia. Wydawało się, że nie ma właściwych słów, by wyrazić znaczenie zdarzeń i odczytać komunikat, jaki ze sobą niosą. W istocie starano się powiedzieć coś więcej, i powiedziano dużo więcej, niż można było zobaczyć. Do tej „pustki rozumienia”, tej porażki języka, dopisano politycznie napędzaną narrację, która zdominowała publiczną wykładnię wydarzeń, a tym samym również możliwych zagrożeń czy ryzyka. Według Jacksona interpretacja ta nie była jednak konieczna czy nieunikniona - można było wybrać zupełnie inną ${ }^{26}$.

„Pustka znaczeniowa” pojawiła się nie tylko w rezultacie ataków terrorystycznych, lecz również w odpowiedzi na nie. W obliczu braku prawnej klasyfikacji aktów terrorystycznych tego rodzaju systematyzacji wymknęła się również rekcja na nie. Język stał się głównym narzędziem moralno-prawnego uzasadnienia działań wojennych, ustanawiania bezpieczeństwa, jak również kreowania zagrożenia i emancypacji ryzyka. Każdy proces wywoływania zgody na działania zbrojne, czyli normalizacji praktyki wojennej, wymaga więcej niż tylko propagandy - wymaga zupełnie nowego języka, narracji publicznej, która jednocześnie wpływa na jej aprobatę. Karen M. Fierke wskazuje, że Sukces lub porażka sekurytyzacji zależy od stopnia, w jakim aktor sekurytyzacji jest w stanie przekonać innych ${ }^{27}$. Podobnie kwestię tę przedstawiają autorzy Security. A New Framework for Analysis: dyskurs, który przybiera formę prezentacji czegoś jako egzystencjalnego zagrożenia dla danego obiektu odniesienia sam w sobie nie stwarza sekurytyzacji, jest to sekurytyzujący ruch, problem zostaje uznany za zagrożenie egzystencjalne tylko wtedy, gdy publiczność zaakceptuje go jako taki wtaśnie $e^{28}$.

Richard Jackson w Writing the War on Terrorism ukazuje, w jaki sposób, za pomocą języka publicznej administracji Stanów Zjednoczonych, urzędnicy stworzyli zupełnie nową rzeczywistość społeczną, a w niej priorytetowe znaczenie przypisano bezpieczeństwu.

W opinii Jacksona główną przyczyną strachu przed terroryzmem stał się „dyskurs zagrożenia” związany z publiczną retoryką normalizującą niepokój publiczny (mimo

25 Zob. G. Borradori, Filozofia w czasach terroru. Rozmowa z Jürgenem Habermasem i Jacques'em Derri$d a$, przeł. A. Karalus, M. Kilanowski, B. Orlewski, red. A. Szahaj, Warszawa 2008, s. 116-117.

26 Zob. R. Jackson, Writing the War on Terrorism. Language, Politics and Counter-terrorism, Manchester-New York 2005, s. 29, 31.

$27 \quad$ K.M. Fierke, Critical Approaches..., s. 114.

28 Zob. B. Buzan, O. Wæver, J. de Wilde, Security. A New Framework..., s. 25. 
rzeczywistego niskiego ryzyka). Władze celowo i starannie skonstruowały głęboki, powszechny strach przed terroryzmem, a język używany do opisania zagrożenia stwarzanego przez terroryzm sprawił, że niepokój uznano za logicznie uzasadniony ${ }^{29}$. Język strachu stał się fundamentem rozbudowanej narracji, którą posłużono się dla moralnej i prawnej legitymizacji działań podejmowanych w tzw. wojnie z terroryzmem. Według Jacksona ataki terrorystyczne zostały przedstawione jako wyjątkowa tragedia niosąca ze sobą egzystencjalne zagrożenie. W podobnym duchu wypowiada się Fierke: Użycie stowa „wojna” w zestawieniu ze stowem "bezpieczeństwo” sugeruje, że niebezpieczeństwo jest egzystencjalne, zagraża istnieniu wspólnoty. Ponieważ zagrożenie jest egzystencjalne, konieczne sá środki nadzwyczajne. Ponieważ zagrożenie jest egzystencjalne, uzasadnione jest zawieszenie zwyczajnej polityki ${ }^{30}$.

Tego rodzaju zabieg z jednej strony usankcjonował odwet wojskowy jako uzasadnioną samoobronę, akt sprawiedliwości, a nie zemsty; z drugiej - przypisał „własność” tragedii Stanom Zjednoczonym (m.in. za sprawą stosowania takich określeń, jak: „narodowa tragedia”, „narodowy szok” itp.). Według Jacksona dyskurs wokół tragedii, która - jak wielokrotnie podkreślano - nigdy nie zostanie zapomniana, stanowi podstawowy motyw kreowania „wojny z terroryzmem”. Badacz uznaje, że mieliśmy do czynienia z dyskursywnym budowaniem narodowego mitu, zaś data 11 września 2001 r. zyskała status ikony wrytej w pamięć narodową z określonym zestawem ukrytych znaczeń i odwołań. Nawet dokładna data okazała się zbędna dla oznaczenia ataków terrorystycznych czy komunikacji ich znaczenia - wystarczający stał się sam symbol „9/11”31.

Najważniejsze dla budowy i wymowy całego dyskursu było uznanie ataku terrorystycznego za „akt wojny”, a nie za zbrodnię przeciwko ludzkości czy masowy mord. Jak podkreśla Jackson, dyskursywna wykładnia, którą posłużyła się administracja Stanów Zjednoczonych, pozwoliła zrekonstruować ataki z 11 września 2001 r. jako działania wojenne, nadając ofiarom podobny status - ofiar wojennych, lecz jednocześnie pozbawiła terrorystów współmiernej legitymacji. W rezultacie „wojna” pozwoliła rządowi Stanów Zjednoczonych działać w sposób, który byłby trudny do zaakceptowania w czasie pokoju. Wojna stała się zupełnie "nową wojną"32: Taka wyktadnia ataków z 11 września 2001 r. jako "nowy" rodzaj dziatań wojennych prowadzonych przez "nowego" rodzaju wroga sprawia, że jest to akt wojny, ale nie w normalnym znaczeniu. Dlatego atakujący nie sa wojownikami ani też nie posiadaja żadnej legitymacji wogóle $e^{33}$. Wszystko, co nie pasowało do tradycyjnych koncepcji „dobrej wojny”, wytłumaczono, bez większych sprzeczności, jako konieczność „innego rodzaj wojny”. „Nowa wojna” zyskała swój szerszy odpowiednik - „nowa epoka terroru”, „nowa era” przemocy terrorystycznej o bezprecedensowym i totalnym charakterze niebezpieczeństw obejmujących

29 Zob. R. Jackson, Writing the War..., s. 94-95. Na temat związku sekurytyzacji z ,wojną z terroryzmem” zob. także K.M. Fierke, Critical Approaches..., s. 112-114.

$30 \quad$ K.M. Fierke, Critical Approaches..., s. 68.

31 Zob. R. Jackson, Writing the War..., s. 31-38.

32 Zob. tamze, s. 38-40.

33 Tami̇e, s. 39. 
zarówno bezpieczeństwo negatywne - bezpośrednio zagraża życiu, indywidualnemu i zbiorowemu przetrwaniu - jak również bezpieczeństwo pozytywne - psychologiczne, kulturowe, polityczne. Zdaniem R. Jacksona jest to jeden z najważniejszych etapów tworzenia dyskursu zagrożeń. Bezprecedensowy i nieprzewidywalny charakter niebezpieczeństw umożliwia korzystanie z zasobów niedostępnych dla polityków w okresach spokoju oraz sprawia, że nikt nie może być obwiniany za brak antycypacji nieoczekiwanego zdarzenia. W związku z tym władze zawieszają obowiązujące normy, stosując środki niezbędne do utrzymania bezpieczeństwa w kraju, takie jak: wojna prewencyjna, zawieszenie praw konstytucyjnych, tymczasowe aresztowania itp. ${ }^{34}$ „Nowa era ludzkiej egzystencji”, „nowy rozdział w historii Ameryki” to przede wszystkim nowe powody do obaw, lęków, niepokojów najczęściej wykorzystywanych w dążeniu do kontroli społecznej. To nowy rodzaj globalnego ryzyka o niepodlegających kalkulacji skutkach; ryzyka stanowiącego uzasadnienie procesu sekurytyzacji.

Sukces sekurytyzacji, a co za tym idzie - możliwość kreowania nowej społecznej rzeczywistości - nie sprowadza się jednak do samego aktu mowy, oświadczenia o stanie wyjątkowym. Perswazyjna siła jednostkowego aktu mowy wymaga ulokowania w szerszych strukturach i relacjach ${ }^{35}$. Zdaniem przedstawicieli postkopenhaskiej teorii sekurytyzacji, aby sukces określonego „ruchu sekurytyzacyjnego” został w pełni zrozumiany, należy przyjrzeć się specyficznym strategiom stosowanym podczas aktu mowy. W jego uzasadnieniu podmioty zazwyczaj czerpią z socjolingwistycznych środków (odwołania emocjonalne, analogie historyczne, różne formy symboliczne, specyficzny język $)^{36}$ znajdujących swój oddźwięk w społecznych oczekiwaniach. Jak wskazuje R. Jackson, w omawianym dyskursie ataki terrorystyczne ukazane zostały jako silnie powiązane $\mathrm{z}$ wieloma istniejącymi wcześniej i bardzo popularnymi metanarracjami, m.in. z Pearl Harbor, zimną wojną, walką cywilizacji z barbarzyństwem. Wykorzystywanie historycznych analogii w celu wyjaśnienia bieżących wydarzeń jest jedną z powszechnie stosowanych metod poznawania i orzekania o rzeczywistości. Ich użycie tworzy określone znaczenia, zasadniczo determinując interpretację tego, co teraźniejsze. Jeśli Saddam Husajn, podobnie jak Adolf Hitler, był bezwzględnym, złym, ekspansywnym dyktatorem - nie było potrzeby żadnych innych wyjaśnień. Jeśli misja USA w „wojnie z terroryzmem" jest analogiczna do tej, którą wojsko wypełniało w II wojnie światowej po ataku na Pearl Harbor ${ }^{37}$, to należy zrealizować ją ponownie - uwolnić świat od terroryzmu. Okazuje się to konieczne, tym bardziej że - jak przekonywała administracja Stanów Zjednoczonych - terroryzm stanowi porównywalne zagrożenie z tym, jakim całkiem niedawno był komunizm. Użyte niegdyś przez Ronalda Reagana pojęcie

Zob. tamże, s. 96.

35 Jest to jeden z podstawowych zarzutów wysuwanych pod adresem przedstawicieli szkoły kopenhaskiej przez przedstawicieli teorii sekurytyzacji drugiej generacji postkopenhaskiej (m.in. Thierry Balzacq, Mark B. Salter, Holger Stritzel).

36 Zob. H. Stritzel, Security in Translation..., s. 44-57.

37 Na temat analogii między „wojną z terroryzmem” a II wojną światową i atakiem na Pearl Harbor zob. R. Jackson, Writing the War..., s. 41-44. 
„imperium zła” powróciło jako „oś zła” w odniesieniu do terroryzmu, a wraz z nim pojawiła się konieczność jego wytępienia ${ }^{38}$.

Jackson jako najczęstszą metanarrację, do której odwoływano się, uzasadniając „wojnę z terroryzmem”, przywołuje powiązanie z jakoby wciąż trwającą walką między cywilizacją a barbarzyństwem. Analogia ta poszerza zasięg ataków terrorystycznych na cały cywilizowany świat. Wydarzenia z 11 września 2001 r. stają się symbolicznym zamachem na wartości oświeconych społeczeństw Zachodu. Napastnicy zostają ukazani jako niszczycielscy totaliści zwalczający wolność, demokrację i postęp; Amerykanie przeciwnie, jako latarnia wolności i demokracji, a co ważniejsze - jako niewinne ofiary nienawistnej agresji. Narracja, w której nowi barbarzyńcy - terroryści - przyrównani zostają do zwierząt, jest kontynuacją cesarskich i kolonialnych postaw, społecznego darwinizmu dzielącego świat na niższe i wyższe rasy ludzkie ${ }^{39}$. Według Jacksona Jest to potężny akt nie tylko kreowania tożsamości dzięki rozróżnieniu na cywilizowanych „nas” i barbarzyńskich „ich”, lecz również dehumanizacji i demonizacji terrorystów $w^{40}$. Nie ulega wątpliwości, że posługiwanie się tego rodzaju językiem - o czym mieliśmy okazję przekonać się wielokrotnie - stwarza warunki do różnego rodzaju nadużyć, m.in. usprawiedliwienia tortur wobec podejrzanych o terroryzm.

Terroryzm jako jedno z głównych światowych niebezpieczeństw stał się przedmiotem antycypacji i inscenizowania za pomocą języka nienawiści i strachu. Można by zapytać - za Jacksonem - dlaczego właśnie terroryzm uznany został za główne zagrożenie publiczne? Dlaczego strach przed nim stał się tak powszechny, gdy rzeczywiste ryzyko dla większości ludzi jest znikome ${ }^{41}$ Nieustanne przewidywanie i inscenizowanie terrorystycznej przemocy połączone z narracją strachu sprawiają, że trudno uchronić się przed niepokojem. Jackson przytacza wiele zwrotów z przemówień przedstawicieli administracji Stanów Zjednoczonych, które pojawiając się nader często i w wielu różnych formach, budują wciąż rosnące poczucie zagrożenia. Terroryzm zatem - jak twierdzą owi urzędnicy - jest: zagrożeniem dla bezpieczeństwa narodowego, polityki zagranicznej i gospodarki Stanów Zjednoczonych; zagrożeniem dla procesu pokojowego na Bliskim Wschodzie; zagrożeniem dla międzynarodowego pokoju i stabilności; zagrożeniem dla stabilności legalnych rządów; zagrożeniem dla Ameryki i naszych przyjaciót i sojuszników; zagrożeniem dla świata; zagrożeniem dla nas wszystkich, którzy wierza w pokój i wolność; zagrożeniem dla tych, którzy szukają nowoczesnego spoteczeństwa; zagrożeniem dla dobrostanu milionów ludzi; zagrożeniem dla bezpieczeństwa narodowego;

38 Na temat analogii między „wojną z terroryzmem” a zimną wojną zob. tamże, s. 45-47.

39 Na temat analogii między „wojną z terroryzmem” a odwieczną walką cywilizacji z barbarzyństwem zob. tamże, s. 47-51.

40 Tamże, s. 49.

41 Dużo większa jest skala ofiar ubóstwa niż osób ginących z rąk terrorystów. Np. w 2005 r. 14600 osób na całym świecie zginęło w atakach terrorystycznych. Dla kontrastu prawie jedna trzecia wszystkich zgonów rocznie, około $18 \mathrm{mln}$, jest związana z ubóstwem. Największa część z nich to ofiary głodu. Rocznie $6 \mathrm{mln}$ dzieci umiera, podczas gdy $161 \mathrm{mln}$ cierpi na chroniczne niedożywienie. W $2010 \mathrm{r}$. 2,4 mld ludzi żyło za mniej niż 2 dolary dziennie, a 1,1 mld - jeden na pięciu - za mniej niż 1 dolara. Zob. K.M., Fierke, Critical Approaches..., s. 31. 
zagrożeniem dla pokoju i wolności; zagrożeniem dla cywilizacji; zagrożeniem dla samej istoty tego, co robisz; zagrożeniem dla naszego sposobu życia; zagrożeniem dla pokoju świata $^{42}$.

Ogrom zagrożeń, które niesie ze sobą terroryzm, potęguje poczucie niebezpieczeństwa, nadając mu charakter wszechobecny. Być może, gdyby nie marginalizacja i wyciszenie odmiennych narracji, „wojna z terroryzmem” pozostałaby jedynie problemem polityki zagranicznej. Antycypacja zagrożeń terroryzmu rodzi pytanie, czy samo w sobie przewidywanie ataków nie stanowi przyczyny nieustannej „wojny”? Takiej wojny, która, jak określa to Jean Baudrillard, tworzy swego rodzaju napięcie związane z obawą, że nigdy się nie skończy; a w związku z tym niepokój będzie nam towarzyszył w przyszłości jako rozproszona aktualność szantażu i terroru w postaci uniwersalnej zasady profilaktyki ${ }^{43}$. Doświadczamy tego dziś. Wydaje się, że antycypacja i inscenizacja terroryzmu, zapoczątkowane w czasie „wojny z terroryzmem”, ani nie powstrzymują, ani nie przeciwdziałają terroryzmowi, przeciwnie, niczym samonapędzająca się machina oliwią jego tryby - napędzają poczucie strachu i zagrożenia. W konsekwencji wywołują one dokładnie przeciwny rezultat od zamierzonego: skutecznie niszczą poczucie bezpieczeństwa zarówno na jego fundamentalnym, egzystencjalnym poziomie, jak i w wymiarze pozytywnym - obniżając jakość życia. Ponadto antycypacja i inscenizowanie zagrożeń nierzadko stają się instrumentem walki o wpływy, władzę, pieniądze - a zatem narzędziem manipulacji. Sekurytyzacja niesie ze sobą realne zagrożenie, manipulacja czy błędna polityka może uczynić świat bardziej brutalnym i niesprawiedliwym - zamiast bezpieczniejszym i bardziej stabilnym. Same ramy „wojny”, w które za sprawą sekurytyzacji wpisano ataki terrorystyczne, najprawdopodobniej zwiększyły zagrożenie i przyczyniły się do pogłębiania konfliktu.

\section{PODSUMOWANIE}

Globalny terroryzm stanowi tylko jeden z przykładów zarządzania ryzykiem i walki z nim. Unaocznia on również konieczność redefinicji pojęcia bezpieczeństwa, a wraz z tym rekonstrukcji naszych historycznych i politycznych narracji. Oznacza to między innymi odejście od rozumienia bezpieczeństwa wyłącznie w sensie negatywnym, sprowadzania go do wymiaru militarnego, znacznie większą wagę przypisując jego pozytywnemu charakterowi. Globalne zagrożenia sprawiają, że pojęcie „bezpieczeństwo” wymaga semantycznego (podmiotowo-przedmiotowego) poszerzenia, domaga się coraz dalszej perspektywy czasowej, w której termin ten będzie rozpatrywany. Globalne zagrożenia, pozbawione przestrzenno-czasowych granic, stają się nie tylko trudne do kontrolowania czy nawet precyzyjnego ich określenia - nowym problemem stał się fakt, że rodzą się one w sercu samego systemu. Trafnie kwestię tę ujął Baudrillard:

Zob. R. Jackson, Writing the War..., s. 99.

43 Zob. J. Baudrillard, The Mask of War, CTheory, 11 III 2005, [online] http://www.ctheory.net/articles.aspx ?id=494, 7 IV 2016. 
wtaściwie porzadek globalny zmaga się z wrogimi sitami rozproszonymi wewnatrz globalizmu, obecnymi we wszystkich wspótczesnych niepokojach ${ }^{44}$. Odnosząc się do terroryzmu, ten sam autor pisat: Nie istnieje już linia demarkacyjna, która pozwolitaby go otoczyć, terroryzm jest w samym sercu kultury, która zwalcza, a widzialne pęnnięcie (a także nienawiść), które w planie globalnym dzieli wykorzystywanych i rozwijających się od świata zachodniego, taczy się potajemnie z systemem wewnątrz dominujacego systemu. System ten jest w stanie stawić czota każdej widzialnej przeciwności. Ale przeciwko innemu, innemu o strukturze wirusa [...] przeciwko takiej formie niemal automatycznej rewersji jego wtasnej mocy system nie może nic. A terroryzm jest fala uderzeniowa tej milczacej rewersji $i^{45}$.

Ta wypowiedź oddaje istotę wszystkich zagrożeń globalnych, nie tylko terrorystycznych, lecz również ekologicznych i finansowych. Nie będąc czymś zewnętrznym wobec systemu (procesu globalizacji), stanowiąc jego integralną część, nie poddają się one kontroli z powodu braku przestrzennych i czasowych granic, dających możliwość skutecznego przeciwdziałania. Realizacja bezpieczeństwa w obszarze globalnym staje się również skomplikowana na skutek samej istoty zagrożeń globalnych, które „rosną w siłę" w miarę rozrastania się samego systemu, niezależnie od tego, czy mamy do czynienia z zagrożeniami będącymi nieumyślnym rezultatem działań podejmowanych w imię bezpieczeństwa (zagrożenia ekologiczne i finansowe), czy z zagrożeniami celowo wywoływanymi przez człowieka (zagrożenia terrorystyczne). Wydaje się, że konstatacja Baudrillarda dotycząca globalnego terroryzmu - uznaje on go za wynik zmagania się triumfujacej globalizacji z sama sobą $q^{46}$ - ma swoje przełożenie na pozostałe światowe zagrożenia. Proces globalizacji i towarzyszące mu zagrożenia zdają się wzajemnie napędzać, a w związku z tym jedynym sposobem przeciwdziałania im jest powstrzymanie samego procesu globalizacji. Można stwierdzić, że globalizacja postępująca w imię szeroko pojętej emancypacji pociągnęła za sobą wysokie koszty w obszarze bezpieczeństwa. W perspektywie "nieprzewidywalnych”, „nieobliczalnych” i „bezimiennych” zagrożeń - jak określił je Zygmunt Bauman - bezpieczeństwo jawi się jako autoreferencyjna praktyka, gdyz [...] problem staje się kwestia bezpieczeństwa niekoniecznie z tego powodu, $\dot{z}$ e istnieje realne zagrożenie egzystencjalne, ale dlatego, że jest przedstawiany jako takie zagrożenie ${ }^{47}$. Sekurytyzacja, wykorzystując retorykę egzystencjalnego zagrożenia, stwarza niebezpieczeństwo świadomego wzniecania niepokoju opinii publicznej dla celów politycznych, manipulowania zbiorowym strachem.

Wiek ryzyka zachęca nas do „sekurytyzacji” wszystkiego, ale często podejmujemy dziatania, nie dysponujac wiarygodna informacja ${ }^{48}$ - czytamy w War in an Age of Risk. Czy sekurytyzacja to jednak wyłącznie sprawne manipulowanie językiem, kwestia interpretacji zdarzeń? Wydaje się, że jest ona wyrazem naszej bezsilności wobec globalnych

\footnotetext{
44 Tenże, Duch terroryzmu. Requiem dla Twin Towers, przeł. R. Lis, Warszawa 2005, s. 15.

45 Tamże, s. 13.

46 Tamże, s. 14

47 B. Buzan, O. Wæver, J. de Wilde, Security. A New Framework..., s. 24.

48 C. Coker, War in an Age..., s. 89.
} 
niebezpieczeństw, niemocy w obliczu poczucia konieczności przeciwdziałania zagrożeniom - przy jednoczesnym braku skutecznych narzędzi.

\section{BIBLIOGRAFIA}

Austin J.L., Jak dziatać stowami, [w:] J.L. Austin, Mówienie i poznanie. Rozprawy i wyktady filozoficzne, przeł. B. Chwedeńczuk, Warszawa 1993.

Baudrillard J., Duch terroryzmu. Requiem dla Twin Towers, przeł. R. Lis, Warszawa 2005.

Baudrillard J., The Mask of War, CTheory, 11 III 2005, [online] http://www.ctheory.net/arti cles.aspx ?id $=494$.

Bauman Z., 44 listy ze świata ptynnej nowoczesności, przeł. T. Kunz, Kraków 2011.

Beck U., Living in the World Risk Society, „Economy and Society” 2006, vol. 35, nr 3.

Beck U., Spoteczeństwa światowego ryzyka. W poszukiwaniu utraconego bezpieczeństwa, przeł. B. Baran, Warszawa 2012.

Borradori G., Filozofia w czasach terroru. Rozmowa zJürgenem Habermasem i Jacquesém Derri$d a$, przeł. A. Karalus, M. Kilanowski, B. Orlewski, red. A. Szahaj, Warszawa 2008.

Bourne M., Understanding Security, New York 2014.

Castells M., The Information Age. Economy, Society and Culture, t. 1: The Rise of the Network Society, Oxford 2000.

Buzan B., Wæver O., de Wilde J., Security. A New Framework for Analysis, London 1998.

Coker C., War in an Age of Risk, Cambridge 2009.

Fierke K. M., Critical Approaches to International Security, Cambridge 2015.

Gasparski W., Systemów teoria, [w:] Filozofia a nauka. Zarys encyklopedyczny, red. M. Iżewska, Wrocław 1987.

Jackson R., Writing the War on Terrorism. Language, Politics and Counter-terrorism, Manchester-New York 2005.

Kostecki W., Strach i potega. Bezpieczeństwo międzynarodowe w XXI wieku, Warszawa 2012.

Lipiec J., Świat wartości. Wprowadzenie do aksjologii, Kraków 2001.

Ogólna teoria systemów. Tendencje rozwojowe, red. G.J. Klir, przel. C. Berman, Warszawa 1976.

Walsh L., Barbara J., Speed, International Security, and „New War" Coverage in Cyberspace, „Journal of Computer-Mediated Communication” 2006, vol. 12, nr 1.

Wæver O., Securitization and Desecuritization, [w:] On Security, red. R.D. Lipschutz, New York 2005.

Dr Jadwiga BŁAHUT-PRUSIK - adiunkt na Uniwersytecie Warmińsko-Mazurskim w Olsztynie, autorka m.in. książki Spór o perspektywy cywilizacji zachodniej. Szkice zamerykanskiejfilozofii spotecznej. 